\title{
Seeking the Productive Energy in Public Debates over Science and Religion
}

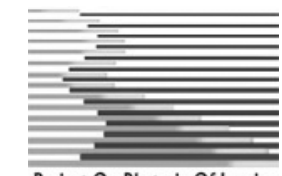

a

POROI

John R. Lyne

Dept. of Communication, University of Pittsburgh

Pittsburgh, PA USA

Joe Rhodes

Dept. of Communication Studies, Louisiana State University

Baton Rouge, LA USA

Ron Von Burg

Dept. of Communication, Christopher Newport University

Newport News, VA USA

\section{Mark A. Steiner}

Dept. of Communication, Christopher Newport University

Newport News, VA USA

Poroi 8, 1 (April 2012)

Science and religion, as institutions woven into the fabric of civil society, are sites of episodic struggles over the direction of human activity. Within these contests, there is often little room for voices of conciliation or for arguments that draw both from science and religion. As a result, the energy from one side tends to counter, rather than harness, the energy of the other. Our panel explored some of the rhetorical conditions and resources that might keep a dialogue between science and religion open, meaningful, and energizing. What follows are the separate voices in this discussion, providing their retrospective accounts. They are therefore in the first person.

\section{John Lyne:}

I began by addressing the preconference theme of "energy," observing that in human affairs energy comes from inspiration-it's the fuel of creativity and achievement. Science and religion were posited as two sources of inspiration. In the case of natural theology, the two can pull in the same direction. Otherwise they either operate in separate spheres or exist in a conflictual relationship. The conflictual relationship is unfortunately quite powerful in the politics of our nation at present, as exhibited in the example of the Republican Congressman who had opened his Bible at a televised hearing on climate change to read God's reassurance that, after the great flood He inflicted on the world, He would not visit such a thing on humankind again. The problem of communicating persuasively between the discourse communities of the scientifically-oriented and the fundamentalist religious-oriented seems 
intractable. In the arena where post-science meets post-religion, one side seems to prosper only when the other is weakened.

But what about those of us who suffer the aching need to be fueled by both physical and transcendent energies? Between scientific atheism and oppressive fundamentalism, what are the possibilities for finding a relationship to the cosmos that brings its wonders close to the heart--that is, in a word, spiritual? Is it possible for those not conventionally theistic to find themselves inspired by the universe itself? The example of Teilhard de Chardin comes to mind. His spiritual and poetic embrace of evolution did not win favor with the Catholic church, but he is enjoying renewed popularity as a result of having foreseen something like a global consciousness, which is how many see the internet. (Yes, we're talking consciousness, not mere "brain function.") I can testify that his writing made a lasting impact on me when I read it as a high school student. With apologies to those who scoff at dualisms, it seems to some of us that some synergistic dualities may be necessarily at play in our world. So, for instance, I pose the question of whether science is always limited to the realm of the "is" with insufficient resources to produce an "ought" and whether technology can ever afford more than "means" to ends that are not themselves technological. Not incidentally, I note that those in our field so eager to eradicate the realm of the "non-material" seem to me to be headed over a cliff. (Why is their vocabulary so alluring to those who have invested in a field premised on the power of consciousness?)

Charles Sanders Peirce said that the essential elements of a religion are Myth (specifically, a myth of origins), Morality (guidelines for behavior), and Mystery. [Let it be noted that a book of essays used as a prop by Joe Rhodes became mysteriously animated during the session.] Could it be that with all the firepower of science and all the analytic skills of "the new atheists," there will always be a hunger for mystery at the core of our world? Science sees a mystery as something to be solved. Religion sees mystery as something to be embraced. In his book on science fiction as mythology, our rhetorician friend James Herrick argues that science fiction has provided a new theology for our times. But how much of that is science, how much is something more mysterious? Even in filmic representations of a technologically superior world, science seems able only to grease the skids toward valued ends, still the latter have something breathy and yearning about them, something full of motivation and desire.

In contemplating "incompleteness" of science, I noted that at the center of the Star Wars saga is a physically wizened emperor, hobbling along with a cane, surrounded by the splendor of imperial storm troopers. In the film Minority Report, technology permits the police to track would-be offenders by constant surveillance; but the core competency is performed by three pathetic "pre-cogs" (humans with precognition floating in a tank of fluid), who foresee crimes before they happen. In the case of the menacing Borg in the Star Trek television series there is only a corporate entity, with no apparent center-yet in the movie version, the dramatic requirements (Burkeans take note) necessitated that there be an evil queen at the center of this otherwise distributed entity. All of this might suggest that there is something both frail and mysterious, fleshy 
and feeling-laden, constrained yet conscious, at the heart of these scientific juggernauts. This seems to me further evidence that humanity lives neither by bread nor breath alone. Post-Hegel, post-Marx, postscientism, post-religion, we need both. Crafting rhetorics that respond to this two-sided yet synergistic need is perhaps-if you will pardon the cosmic gesture-among the highest tasks of our species.

\section{Joe Rhodes:}

Looking back on the luminous and lively spirit of C.S. Peirce, which seemed incarnate within his collection of essays, which lept from the table in front of us, I can't help but think there are two reasons he may have been announcing his frustration and disagreement with all of us. Indeed, we have sinned against the God of Empiricism (and we should note that Science has no right to claim Him as hers alone). Peirce would probably disapprove of how, in our panel conversations and presentations, we only skirted, and sometimes outright ignored, the lived experiences of what Reinhold Niebuhr calls "the man on the street." I would pose that the real problem is a political one between two institutions with conflicting interests, both material and moral, and further, that this problem does not necessarily translate into an actual problem in the lived experiences of average person (yes, I said "average"!)--who is busy paying bills, looking for a job, spending time with grandchildren, and not very often debating whether God and evolutionary biology are compatible. In fact, a growing number of Westerners report that they are "spiritual" but not "religious." This seems to be their way of moving past the false dualism altogether. Regarding this empirical observation, I'm not sure Religion vs. Science are in such a fight to the death as we often suppose.

This brings me to a second point. We have sinned against the God of Existentialism, the son of the God of Empiricism and half-brother of the God of Phenomenology. There is a difference between politics and religion/science vs. political theology, the study of the ultimate "good" and how we organize ourselves around an attempt to actualize that ideal in collective action. Often our discussion of these issues obscures the real dilemma that faces every generation and every Being: Kierkegaard called it the anxiety of choosing a belief in fear and trembling, Niebuhr called it the threat of despair and cynicism that comes from seeming meaninglessness. Tillich called it mustering up the Courage to Be. Whatever you call it, it is important that we separate man's existential problems from the West's political problems, whenever we pit religion and science against one another in a rhetorical skirmish.

Aristotle remains a corrective, even today, reminding us that dialectic is the counterpart of rhetoric and not that much has changed since Socrates insisted that we define our terms before we commence examining problems and posing solutions. Peirce demands by leaping from our table (in what can only be called "handsome and charming glory") that we "make our ideas clear." We rhetoricians, of all people, should know better than to set-up what may be false binaries, and then start analyzing "voices of moderation" between them. To paraphrase the God of Christianity, "We have all sinned and fallen short of the glory of C.S. Peirce." 


\section{Ron Von Burg and Mark Steiner:}

Moments of mutual disdain between the scientifically-inclined and the religiously-driven are manifest in caustic public discourse that leaves little space for moderate voices. Too often, we focus on how religious figures who disparage science pollute civil discourse with righteous claims of moral certitude, casting dissenters as misguided sinners, and ignoring evidence grounded in scientific rationality. However, the scientificallydriven are equally culpable of sullying civil public dialogue with absolutist statements that convey a condescending tone of intellectual judgment. To wit, the New Atheists, led by the likes of Richard Dawkins, Daniel Dennett, and Sam Harris, offer scathing critiques of even moderate brands of religious faith. Even as moderate voices suggest that religion offers a moral compass to guide science, the New Atheists reject such suggestions as yet another iteration of irrational thought.

In The Moral Landscape, Harris (2010) suggests that neuroscience can reveal a new moral framework based on human well-being, replacing the non-rational religious foundations of morality. But Harris saves his most virulent attacks for scientists who adhere to religious convictions, such as Human Genome Project leader Dr. Francis Collins, a devout evangelical Christian. Collins embraces evolution and promotes the value of stem-cell research, but he identifies his faith as a source of inspiration for his scientific pursuits. For Harris, such a position invariably taints Collins' scientific credentials. Harris positions himself as an ardent defender of science, suggesting science will inevitably answer all questions we may have, even questions that Collins answers with his faith.

Neuroscience, like many other scientific attempts before it, may be able to answer some of the fundamental questions of existence. It may even provide some guidance as to how we process moral claims, perhaps even pointing the way toward more ethical decisions. However, Harris's rhetoric, along with the other New Atheists, lacks the sensitivity necessary to sustain a civil public discourse. More specifically and fundamentally, Harris brings an epistemological shortsightedness to his understanding of the scientific enterprise. This myopia predisposes him to misunderstand the function and scope of science and thereby improperly to exaggerate what it can and should do. Harris' rhetorical strategy cultivates a public discursive climate that is unfavorable to the practice of what Wayne Booth (2006) called "rhetorology" and what Eugene Garver (2006) has called "the hermeneutic principle of charity." As a result, Harris offers a caricature of the scientific establishment that degrades efforts to establish a suitably modest yet serious and credible public voice for science on important public policy issues. 


\section{References}

Booth, W.C. (2006). Science versus religion: Can rhetorology yield an armistice? In J. B. White (Ed.), How should we talk about religion?: Perspectives, contexts, particularities (pp. 144-163). Notre Dame, IN: University of Notre Dame Press.

Garver, E. (2006). How can a liberal listen to a religious argument? Religious rhetoric as a rhetorical problem. In J. B. White (Ed.), How should we talk about religion?: Perspectives, contexts, particularities (pp. 164-193). Notre Dame, IN: University of Notre Dame Press.

Herrick, J.A. (2008). Scientific mythologies: How science and science fiction forge new religious beliefs. Downer's Grove, IL: InterVarsity Press.

Harris, S. (2010). The moral landscape: How science can determine human values. New York, NY: Free Press.

Peirce, C. S. (1955). Philosophical writings of Peirce. New York, NY: Dover Publications. 